\title{
Kerk en geloof in Holland in die stryd teen apartheid (1950-1980)
}

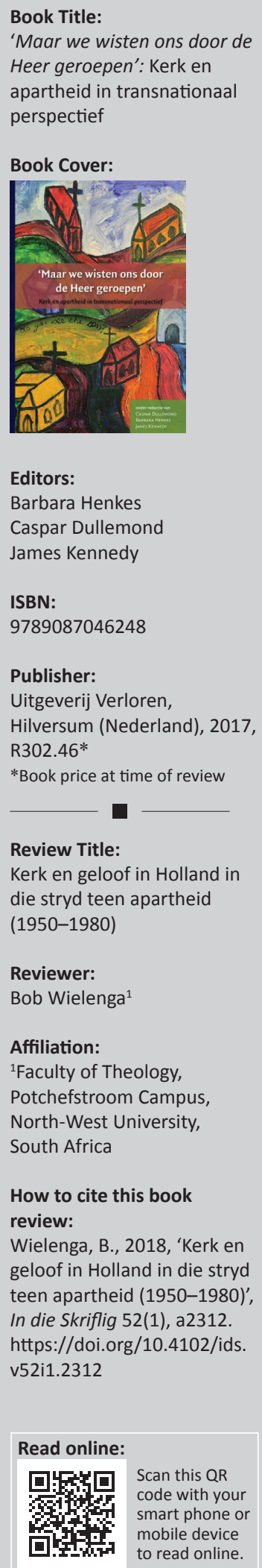

Voor die bloedbad in Sharpeville (1960) was daar min belangstelling in Holland in die politieke verwikkelings in Suid-Afrika sedert 1948. Daar was egter uitsonderings soos die Hervormde dominee J.J. (Jan) Buskes wat reeds in 1955 'n boek teen die apartheidbeleid gepubliseer het. Hierdie belangstelling was aan die ontwikkel weens rasse-ongelykheid. Ook sy vroeëre studiegenoot, die (latere) gereformeerde sendinghoogleraar Johan Bavinck het sy stem teen apartheid laat hoor. Albei was in kontak met die Stellenbosse hoogleraar in dogmatiek Bennie Keet wat juis ook in daardie tyd sy geskrif 'Suid-Afrika - waarheen?' publiseer. Al drie was studente van die VU-hoogleraar Herman Bavinck. Bavinck was naas Abraham Kuyper die grondlêer van die neo-Calvinisme. Kuyper se weergawe daarvan het grootliks tot die fundering van die apartheidfilosofie bygedra. Ons moet ook Christiaan Beyers Naudé, die direkteur van die Christelike Instituut, by hierdie netwerk inreken. Hierdie inligting, ontleen aan die hoofstuk wat George Harinck tot hierdie boek bydra, toon duidelik dat hierdie studie oor die kerk en apartheid in transnasionale perspektief geskryf word. Die drie redakteurs, naamlik die bekende Hollandse geskiedkundiges Caspar Dullemond, Barbara Henkes en James Kennedy dui aan dat hulle ondersoek oor die wyse handel waarop kulturele oordrag tussen individuele gelowiges, kerkleiers en -institusies vorm gegee het aan die bespreking en die stryd oor apartheid in Holland. Daar het oor nasionale grense heen netwerke ontstaan van mense, maar ook van institusies soos kerke. Dit het mekaar in die beoordeling van apartheid beïnloed, en so ook aan die stryd daarteen rigting gegee. In hierdie boek werk die skrywers, almal deskundiges op hulle gebied, met die konsepte van 'vervlochten geschiedenissen' en 'culturele en politieke transfer' (bl. 11). 'n Mooi voorbeeld van hierdie werkswyse is Retief Müller se bydrae oor Beyers Naudé wat netwerke oor die kleurgrens in Suid-Afrika, maar ook in Europe ontwikkel het. Binne hierdie netwerke kon die deelnemers mekaar oor en weer kruisbestuif.

Dieselfde kom ook duidelik na vore in Wouter Marchand se bydrae oor die rol wat Jan Buskes in die Nederlands Hervormde Kerk (NHK) gespeel het. Hy het by die Engelse anti-apartheidbeweging, Christian Action, denkbeelde en aksieplanne oorgeneem en in Holland tot uitvoering gebring. Die Afrikaner Patrick van Rensburg het die Engelse verset teen apartheid in Holland verteenwoordig. Trevor Huddleston het op 'n soortgelyke wyse invloed op die Hollandse antiapartheidbeweging uitgeoefen. Veral die Hoogverraadverhoor (1955-1961) het in Europa mense regop laat sit en in beweging gebring. Verskillende Hollandse anti-apartheidorganisasies soos Comité Zuid-Afrika, waaruit Kairos later voortgekom het, is deur Buskes geïnisieer. Daarby was daar ook voortdurende beraadslaging met die konneksies in Suid-Afrika soos Beyers Naudé.

Die NHK het reeds vroeg by die Wêreldraad van kerke (WRK) se program, To combat racism (1961), aangesluit. Dit het egter tot 1978 geduur voordat die Gereformeerde Kerken (GKN) meegedoen het. Daardie moeisame worsteling binne die GKN rondom die aansluiting by die WRK se antiapartheidstryd waarby geweld ook ingesluit was, word noukeurig deur Yara van 't Groenewout beskryf. Daar was binne die GKN soos trouens ook binne die NHK (die Gereformeerde Bond), 'n sterk beweging om kontak met die stamverwante Afrikanervolk te behou. Hulle was immers ook deur die Calvinisties-gestempelde geloof verbind. Hierdie GKN-faksie het vir dialoog en teen geweld gepleit. Die moord op Steve Biko (1977) het egter tot die Sinodebesluit van 1978 gelei, naamlik om die WRK se beleid wel te steun, insluitend geweld teen die apartheidsbewind. Ook hier het transnasionale kontakte'n rol gespeel, waarby aan die VU-sendinghoogleraar J. (Johannes) Verkuyl gedink kan word. Daar word ook breedvoerig beskryf hoe die kerklike kontakte tussen die GKN aan die een kant en die Nederduits Gereformeerde Kerke (NGK) asook die Gereformeerde Kerke in Suid-Afrika (GKSA) aan die ander kant rondom hierdie tema verloop het.

By die besluitvorming binne die GKN het swart studente (soos Mpho Ntoane, Takatso Mofokeng en Allan Boesak) uit Suid-Afrika 'n rol gespeel. Deur bemiddeling van die Christelike Instituut en later ook die Belydende Kring (NGK) het hulle na Holland gekom om hulle teologiese studie

Copyright: @ 2018. The Authors. Licensee: AOSIS. This work is licensed under the Creative Commons Attribution License. 
te voltooi. Erica Meijers beskryf hoe die ontmoeting van wit Gereformeerde Hollanders met die swart ervaring van apartheid afgeloop het. Die studente het hulle standpunte in preke, toesprake en gesprekke tot op Sinodevlak binne die GKN verduidelik.

'n Aparte hoofstuk is deur Barbara Henkes aan familiegeskiedenis gewy as voorbeeld van ' $n$ transnasionale netwerk. Daar het spanning tussen families ontstaan wat na Suid-Afrika geëmigreer en hulleself daar met die norme en waardes van die Afrikaner nasionalisme geïdentifiseer het, én die familie wat in Holland agtergebly en mettertyd ander sienswyses ontwikkel het. Daar het ' $n$ breuk in die familie gekom toe 'n Hollandse niggie met 'n swart Surinamer getrou het. Hulle gedeelde geloof kon die familie nie bymekaar hou nie. Die familieband is verbreek.

Daar was natuurlik ook kerke in Holland wat 'n ander koers met betrekking tot die apartheidsbeleid in Suid-Afrika ingeslaan het. Bernard Slaa beskryf die geskiedenis van die NHK-dominee G.J.H. (Han) Gijmink wat aan die hoof van die Nederlands Suid-Afrikaanse Werkgemeenschap (NSAW, later ANW) gestaan het. Hy het die verspreiding van die apartheidsideale in Holland as 'n goddelike roeping gesien. Hy het veral kontakte met die Nederduits Hervormde Kerk in Suid-Afrika gehad. Gijmink het die Christelike sending veral gesien as 'n 'oplossing en heilige plicht om de onthechtheid van die Afrikaanse volkeren, die door westerse techniek en wetenschap ontworteld waren van hun eeuwenoude stamgewoonten en volksculturen, te niet te doen' (p. 162). 'n Ander konserwatiewe kerklike groepering in Holland wat die ontwikkelings in Suid-Afrika onkrities gesteun het, was die Vrijgemaakte Gereformeerde Kerken (GKv) wat in Suid-Afrika veral kontakte met hulle susterkerke, naamlik met die Vrye Gereformeerde Kerke (VGK) behou het. Die VGK het uit die na-oorlogse Hollandse immigrasie voortgekom en is veral in Gauteng gekonsentreer. Caspar Dullemond gee 'n duidelike oorsig oor die geskiedenis van die verhouding tussen die GKv en die GKSA. Dit is sterk deur die absolutistiese kerkvisie van die GKv gekleur waarin geen plek vir 'n profetiese rol van die kerk in die samelewing ingeruim is nie. Ook in die GKv het die moord op Biko tot die begin van 'n kritiese benadering tot apartheid gelei (publikasies van die etiek-hoogleraar Jochem Douma sedert 1978. 'n Verwysing na VU-Professor Bob Goudzwaard se publikasies ontbreek egter). Kees van der Waal wat in die VGK van Pretoria grootgeword het, beskryf aan die hand van sy eie verhaal die posisie van daardie kerke in Suid-Afrika se apartheidstelsel. Hy verwerk in sy artikel die bydrae van ander persone in die beskrywing van sy ontwikkeling van volkekundige na 'anthropologist'.

Hierdie boek word aanbeveel weens sy insiggewende analises van die komplekse verhouding tussen stamverwante kerke en gelowiges in Holland en Suid-Afrika. In die krisis waardeur daardie verhouding gekom het, het albei partye deur die Here geroepe gevoel en daarvolgens opgetree. 